\title{
Occurrence of gastric ulcers in horses exercised on a treadmill
}

\author{
Ocorrência de úlceras gástricas em cavalos exercitados em esteira rolante
}

\author{
Gesiane Ribeiro $^{\mathrm{I}^{*}}$ Luis Cláudio Lopes Correia da Silva ${ }^{\mathrm{II}}$ Carla Bargi Belli ${ }^{\mathrm{II}}$ \\ Leonardo Paiao Vargas ${ }^{\mathrm{I}}$ Maria Letícia Tescaro Piffer ${ }^{\mathrm{II}}$ Maurício Mirian \\ Vanessa Aparecida Feijó de Souza ${ }^{I}$ Wilson Roberto Fernandes ${ }^{I I}$
}

\section{ABSTRACT}

The most frequently causes of gastric ulcers in horses are fasting, feeding type and management, as well as administration of certain medications. More recently, exercise has also been identified as an important factor in the development of gastric lesions in athlete horses. The purpose of the present study was to assess whether treadmill exercise predisposes the horses to the occurrence of gastric ulcers. Five Arabian horses underwent a twelve-week training period on a treadmill and a gastroscopic evaluation before and after the training period. All animals showed gastric lesions after the training period. Based on these results, it is concluded that Arabian horses undergoing exercise on a treadmill may develop gastric lesions varying in number and severity.

Key words: Arabian horses, exercise, gastric lesions, stress.

\section{RESUMO}

As causas mais frequentes de úlceras gástricas em cavalos são jejum, tipo de alimentação e manejo, bem como a administração de alguns medicamentos. Mais recentemente, o exercício também foi identificado como um fator importante no desenvolvimento das lesões gástricas em cavalos atletas. O objetivo do presente estudo foi avaliar se o exercício em esteira rolante predispõe os cavalos à ocorrência de úlceras gástricas. Cinco cavalos árabes foram submetidos a um período de doze semanas de treinamento em esteira rolante e a avaliação gastroscópica antes e após o periodo de treinamento. Todos os animais apresentaram lesões gástricas após o treinamento. Com base nesses resultados, conclui-se que cavalos árabes submetidos a exercício em esteira rolante podem desenvolver lesões gástricas em número e gravidade variados.

Palavras-chave: cavalos árabes, exercício, lesões gástricas, estresse.

\section{INTRODUCTION}

Considering the importance of exercise as a predisposing factor for gastric ulceration in horses, some researchers have sought to relate the incidence of gastric lesions to athletic activity. A study on the prevalence of gastric ulcers in racehorses reported occurrence rates of $56 \%$ in "non-professional" animals and $93 \%$ in intensively trained horses (ROY et al., 2005). In a population of 94 racehorses the occurrence of gastric ulcer was 74.5\% (MARQUÉS et al., 2011). Another study had reported that $79.5 \%$ of racehorses evaluated had gastric lesions (SCHAEFER et al., 2006).

In 2011, the effect of training and competing on the incidence of gastric lesions in high athletic level endurance horses was investigated. The animals were evaluated in two periods of the year, during the resting season and then during the competition season. The authors reported an incidence of $43 \%$ during the resting period and $93 \%$ during the competitions (TAMZALI et al., 2011).

Therefore, it becomes increasingly evident that athletic activity influences the occurrence of gastric lesions in horses. However, it is not yet known to which extent exercise is responsible for the development of gastric lesions, independent of the influence of other factors already established as the cause of injury. This justifies the need for a study to assess the influence of exercise on the occurrence of

\footnotetext{
'Faculdades Metropolitanas Unidas (FMU), Campus Ponte Estaiada, Hospital Veterinário, 05690-050, São Paulo, SP, Brasil. E-mail: gesiane.ferraz@fmu.br. "Corresponding author.

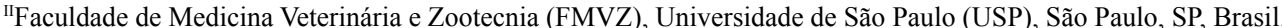
Received 06.13.15 Approved 09.24.15 Returned by the author 03.02.16 CR-2015-0856.R1
} 
gastric lesions in horses subjected to an experimental training protocol, in which the animals are free from other potentially triggering factors of gastric lesions; such as the frequent use of NSAIDs, prolonged fasting periods, stress caused by transport, environmental changes and management (ANDREWS et al., 2005), so common in the lives of athlete horses in competition periods. The purpose of the present study was to assess whether treadmill exercise predisposes Arabian horses to the occurrence of gastric ulcers.

\section{MATERIALS AND METHODS}

Five clinically healthy adult horses that were for at least three months without practicing controlled physical activity were evaluated. The male and female Arabian horses, weighing between 320 and $350 \mathrm{~kg}$, were stabled in stalls, fed with coast cross hay and water ad libitum, and supplemented with commercially available rations for horses and mineral supplement.

Upon arrival, the animals underwent a 60day adaptation period to the feeding management and the environment, including the treadmill room and people involved with the research. During this period, the animals were gradually adapted to walking on the treadmill belt, initially pulled by the halter on the stopped treadmill belt and then on the moving treadmill, with and without tilt.

After the adaptation period, one Standard Progressive Exercise test was performed before the start of training period. It was divided into 8 stages lasting 3 minutes each, at progressive speeds of 2.5 , $3.3,4.1,5.0,6.6,8.3,10,12.5 \mathrm{~ms}^{-1}$ with treadmill tilt of $6 \%$. The test was stopped when the horses could no longer keep up with the speed of the treadmill, even when stimulated. The maximum heart rate achieved by each animal during the Standard Progressive Exercise Test was used to determine the speed to which they were subjected during training.

Horses were trained in the Laboratory of Equine Sports Medicine of FMVZ/USP, during 30 to 40 minutes a day, four days a week, for 12 weeks, achieving the speed at which the animals reached $60 \%$ of their maximum heart rate.

Two gastroscopic evaluations were performed in each animal. The Control Group evaluation was performed soon after the adaptation period, i.e., at the time when the animals were free of stress factors such as transportation, environmental changes, feeding and management. The second evaluation was performed at the end of the training period and has been defined as Training Group.
For gastroscopic examination, the animals underwent an 18-hour feed fasting period and 6 hours without water intake, as well. Each animal was then restrained in the horse stock and received detomidine (Dormiun V, Agener União, Brazil) at $0.01 \mathrm{mgkg}^{-1}$ intravenously. Five minutes later, a three-meter long flexible endoscope was introduced into the nostril, through the nasopharynx, oesophagus, reaching the stomach of the animal. After carefully evaluating the obtained images, the lesions were classified by blinded researchers according to two methodologies: Grade A (MACALLISTER et al., 1997) that assigns scores for the number and severity of lesions, and Grade B (BELLI, 2001) that assigns a total score for the stomach considering not only the presence, severity and extent of ulcers, but also other findings such as the occurrence of gastritis (mild, moderate or severe), hyperkeratosis and desquamation of the mucosa.

The results obtained for both the Control and Training Groups were compared with respect to the number and severity of injuries (Grade A) and total score (Grade B). To determine the statistical significance of the results the Wilcoxon test was conducted at 0.05 significance, given the sample size $(\mathrm{n}=5)$. Statistical Analysis was performed using the SPSS v.9 software.

\section{RESULTS AND DISCUSSION}

The gastroscopic evaluation of the Control Group showed that three horses had no lesions and two horses had minimum number of low severity lesions, scoring 1 and 3 according to Grade A and Grade B rating methodology. Conversely, the gastroscopy performed at the end of the training period showed that all horses had lesions that varied in number and severity. The animals that had already presented injury in the first assessment had their scores increased for both number and severity of lesions.

Statistical analysis comparing the gastroscopic evaluation results of both groups (Control and Training Groups) showed significant differences in relation to the number of lesions (Figure 1), severity of lesions (Figure 2) and total score of gastroscopic findings (Figure 3 ).

These results support the hypothesis that treadmill exercise can be seen as a predisposing factor for the development of gastric ulcers in horses. Animals of the control group had either no damage or a very small number of low severity lesions before starting the proposed training, while at the end of the training period both number and severity of the lesions were significantly higher. 

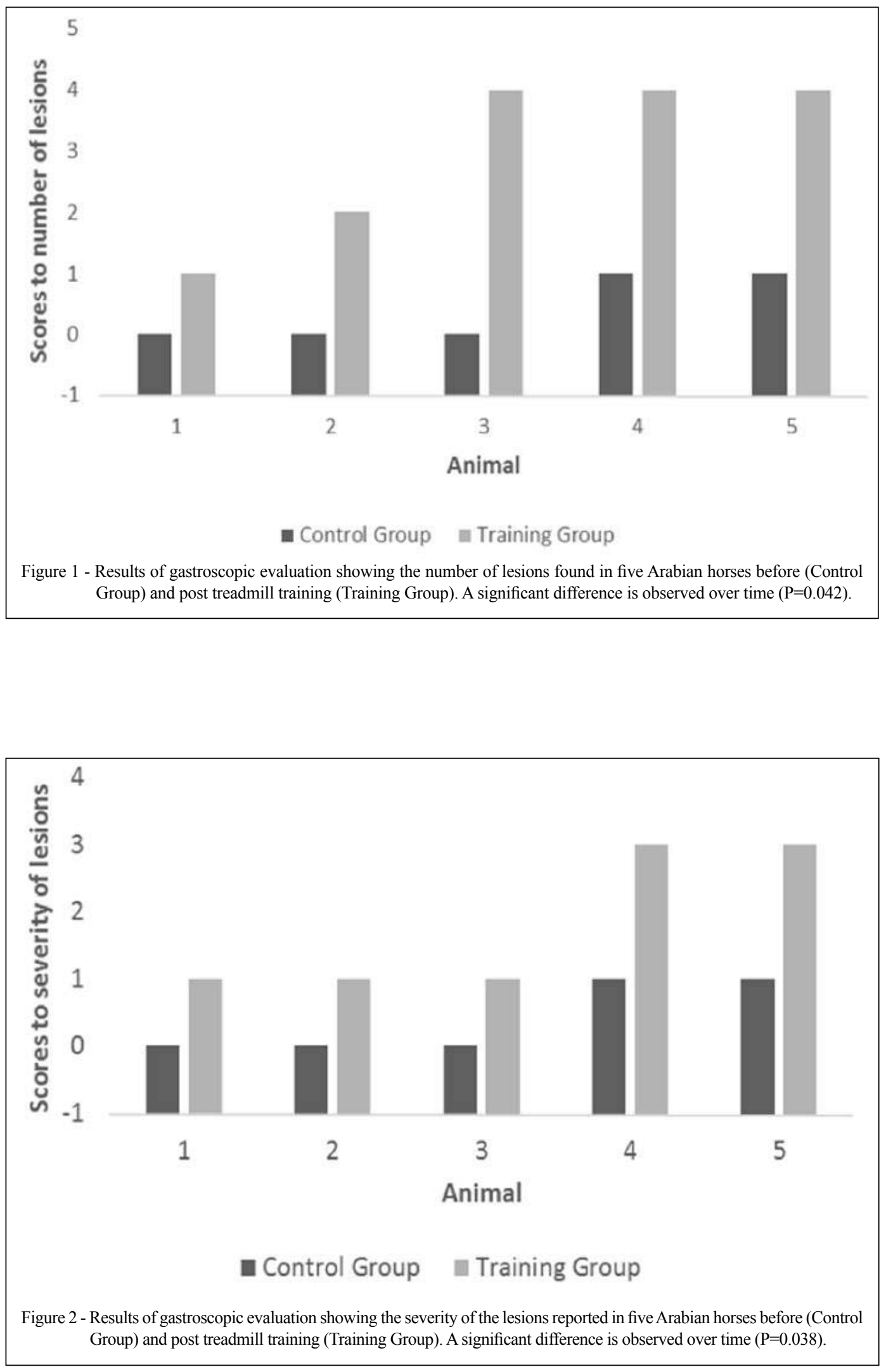

Ciência Rural, v.46, n.5, mai, 2016. 


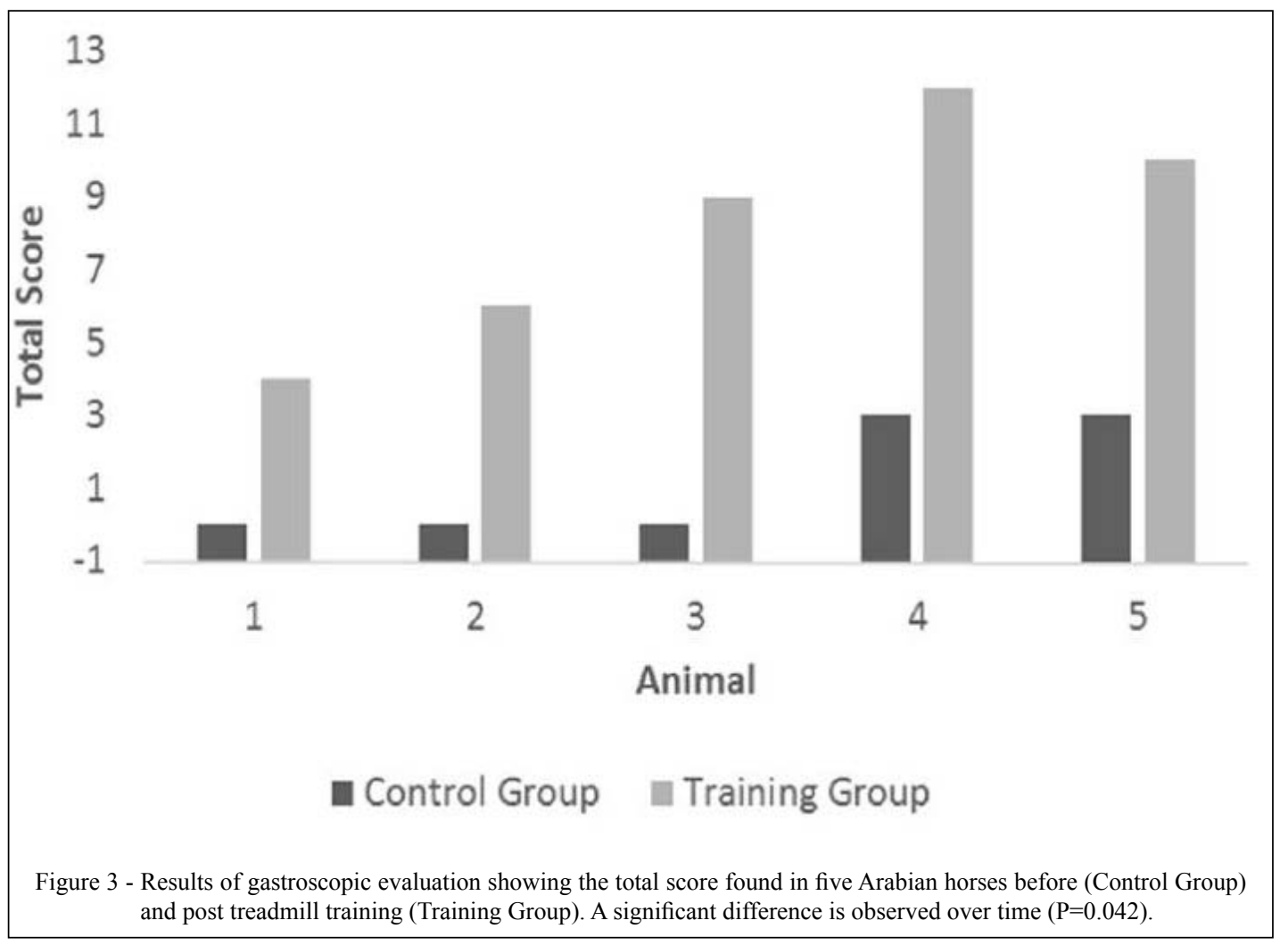

The delay in gastric emptying and decreased gastro-duodenal motility as a result of exercise can increase the exposure time of the squamous mucosa to gastric contents, similar to what occurs in humans with gastro-oesophageal reflux pathology, when the squamous mucosa of the oesophagus is injured by contact with the gastric contents (SHAWDON, 1995). The gastric juice contains substances that are potentially harmful to the squamous mucosa of the stomach proximal portion and hydrochloric acid has been singled out as the major ulcerogenic factor, since treatment with antacids reduces clinical signs and lesions in humans (PETERS et al., 1999) and in horses (MURRAY et al., 1997).

Furthermore, the pressure exerted by the abdominal muscles and respiratory movements on the stomach during exercise can increase the intra-gastric pressure or mix the gastric contents, thus breaking the $\mathrm{pH}$ gradient that exists in the stratification of food contents in order to prevent exposing the squamous mucosa to high concentrations of acid (BAKER \& GERRING, 1993). A research with horses that exercised on a high-speed treadmill confirmed the occurrence of gastric compression resulting from the increased abdominal pressure during exercise (LORENZOFIGUERAS \& MERRITT, 2002).

In this study, the sixty-day adjustment period to which the animals underwent before starting training aimed to exclude, or at least minimize, management or treadmill exercising related stressors which could act as a trigger for gastric lesions, since it is known that stress can also contribute to the occurrence of gastric ulcers in horses (ORSINI et al., 2009).

There are reports in the literature of gastric ulcer and duodenal perforation in foals subjected to stress from handling, medication and transportation, situations that potentially involve several stressors, such as physical (noise and vibration) and emotional factors (the unknown environment and social reintegration) (BORROW, 1993). Stress is one of the most important factors causing gastritis in human patients in Intensive Care Units. The mechanism is explained by the release of catecholamines, resulting in vasoconstriction, ischemia of the gastric mucosa, loss of resistance, scaling and backscattering of acid to the lamina propria (MEIRELLES FILHO \& ANDRÉ, 2000). Gastric ulceration can result from a reduced focal capillary perfusion secondary to high amplitude and low speed contractions of the stomach. 
These contractions cause a blood outflow from the capillaries and when prolonged, they limit perfusion for a long enough period of time for the acid to cause the injury (MURRAY, 1991).

The two horses that had already presented minor injuries in the first gastroscopic evaluation, i.e., after the adjustment period and before starting the exercise, had a marked increase in both number and gravity of gastric ulcers. Moreover, it has been previously reported in the literature, in a study that performed two endoscopies within a three-month interval that spontaneous healing of existing gastric ulcers in horses is not common and the lesions tend to aggravate when animals remain in training (MURRAY \& EICHORN, 1996).

Regarding clinical signs, it is known that adult horses with gastric ulcer may present capricious appetite, behaviour changes, weight loss and colic (ANDREWS \& NADEAU, 1999). However, nonspecific clinical signs, such as apathy or decreased performance, are quite frequent, while many animals with gastric ulceration may not display obvious signs (JONES, 2006). In the present study, the horses displayed no obvious change suggesting the occurrence of gastric lesions. Therefore, gastroscopic evaluation of horses with or without clinical signs is of utmost importance to diagnose gastric lesions and monitor the healing process, as well. Endoscopy is the only accurate method to diagnose gastric lesions and monitor treatment effectiveness because it allows visualizing the extent and severity of lesions (FERNANDES et al., 2003).

\section{CONCLUSION}

Based on these results, it is concluded that Arabian horses undergoing treadmill exercise may develop gastric lesions varying in number and severity. The possible influence of these lesions on athletic performance and other parameters should be considered by researchers studying the physiology of equine exercise.

\section{ACKNOWLEDGMENTS}

This study was funded by Fundação de Apoio à Pesquisa do Estado de São Paulo (FAPESP 2012/10886-3).

\section{BIOETHICS AND BIOSSECURITY COMMITTE APPROVAL}

This study was approved by the Ethics Committee on Animal Use (CEUA) of Universidade de São Paulo (USP), São Paulo/SP, Brazil (protocol number 1741).

\section{REFERENCES}

ANDREWS, F.M. et al. Gastric ulcers in horses. Journal of Animal Science, v.83, suppl.13, p.E18-E21, 2005. Available from: $\quad<$ http://www.animalsciencepublications.org/publications/ jas/articles/83/13_suppl/0830018?highlight=\&search-result=1>. Accessed: Jun. 08,2015. doi:/2005.8313_supplE18x.

ANDREWS, F.M.; NADEAU, J.A. Clinical syndromes of gastric ulceration in foals and mature horses. Equine Veterinary Journal, v. 31, Suppl.29, p.30-33, 1999. Available from: <http:// onlinelibrary.wiley.com/doi/10.1111/j.2042-3306.1999.tb05165.x/ epdf>. Accessed: Jun. 08, 2015. doi: 10.1111/j.2042-3306.1999. tb05165.x.

BAKER, S.J.; GERRING, E.L. Technique for prolonged, minimally invasive monitoring of intragastric $\mathrm{pH}$ in ponies. American Journal of Veterinary Research, v.54, p.1725-1734, 1993.

BELLI, C.B. Comparação entre os achados gastroscópicos de equinos adultos sadios e de equinos com suspeita de úlcera gástrica. 2001. 119f. Dissertação (Mestrado em Medicina Veterinária) - Faculdade de Medicina Veterinária e Zootecnia da Universidade de São Paulo, SP.

BORROW, H.A. Duodenal perforations and gastric ulcers in foals. Veterinary Record, v.132, p.297-299, 1993. Available from: <http://veterinaryrecord.bmj.com/content/132/12/297. abstract? sid $=225$ e 8 ef5-07c4-477e-984f-79e4b803839a $>$. Accessed: Jun. 08, 2015. doi: 10.1136/vr.132.12.297.

FERNANDES, W.R. et al. Achados gastroscópicos em equinos adultos assintomáticos. Arquivo Brasileiro de Medicina Veterinária e Zootecnia, v.55, p.405-410, 2003. Available from: $<$ http://cpro4576.publiccloud.com.br:8080/editora-consulta/artigo/ exibir/exibirArtigo.do?codigo=520>. Accessed: Jun. 11, 2015.

JONES, M.P. The role of psychosocial factors in peptic ulcer disease: beyond Helicobacter pylori and NSAIDs. Journal of Psychosomatic Research, v.60, p.407-412, 2006. Available from: <http://www.jpsychores.com/article/S00223999(05)00313-2/pdf>. Accessed: Jun. 08, 2015. doi: 10.1016/j. jpsychores.2005.08.09.

LORENZO-FIGUERAS M.; MERRITT, A.M. Effects of exercise on gastric volume and $\mathrm{pH}$ in the proximal portion of the stomach of horses. American Journal Veterinary Research, v.63, p.14811487, 2002. Available from: <http://avmajournals.avma.org/doi/ pdf/10.2460/ajvr.2002.63.1481>. Accessed: Jun. 08, 2015. doi: 10.2460/ajvr.2002.63.1481

MACALLISTER, C.G. et al. A scoring system for gastric ulcers in the horse. Equine Veterinary Journal, v.29, p.430433, 1997. Available from: <http://onlinelibrary.wiley.com/ doi/10.1111/j.2042-3306.1997.tb03154.x/epdf>. Accessed: Jun. 08, 2015. doi: 10.1111/j.2042-3306.1997.tb03154.x.

MARQUÉS, F.J. et al. The prevalence and risk factors of oesophageal and nonglandular gastric lesions in Thoroughbred racehorses in Saskatchewan. Equine Veterinary Education, v.23, n.5, p.249-254, 2011. Available from: <http://onlinelibrary.wiley. com/doi/10.1111/j.2042-3292.2010.00175.x/epdf>. Accessed: Jun. 10, 2015. doi: 10.1111/j.2042-3292.2010.00175.x.

MEIRELLES FILHO, J.S.; ANDRÉ, E.A. Gastrites. In: CORDEIRO, F.T.M. et al. Endoscopia digestiva - Sociedade 
brasileira de endoscopia digestiva. 3.ed. Rio de Janeiro: MEDSI, 2000. 713p.

MURRAY, M.J. The pathogenesis and prevalence of gastric ulceration in foals and horses. Veterinary Medicine, v.86, n.8, p.815-819, 1991.

MURRAY, M.J.; EICHORN, E.S. Effects of intermittent feed deprivation with ranitidine administration, and stall confinement with ad libitum access to hay on gastric ulcerations in horses. American Journal Veterinary Research, v. 57, n.11, p.1599-1603, 1996.

MURRAY, M.J. Overview of equine gastroduodenal ulceration. Phoenix, Arizona, 1997. In: ANNUAL CONVENTION OF THE AMERICAN ASSOCIATION OF EQUINE PRACTITIONERS, 43., 1997, Phoenix, Arizona. AAEP Proceedings... Phoenix: AAEP, 1997. V.43, 434p., p.382-387. Available from: <http:// www.ivis.org/proceedings/AAEP/1997/Murray.pdf $>$. Accessed: Jun. 11, 2015.

ORSINI, J.A. et al. The effect of exercise on equine gastric ulcer syndrome in the thoroughbred and standardbred athlete. Journal of Equine Veterinary Science, v.29, n.3, 2009. Available from: <http://www.j-evs.com/article/S0737-0806(09)00025-2/pdf>. Accessed: Jun. 10, 2015. doi: 10.1016/j.jevs.2009.01.006.

PETERS, H.P. et al. The effect of omeprazole on gastro-esophageal reflux and symptoms during strenuous exercise. Alimentary
Pharmacology and Therapeutics, v.13, p.1015-1022, 1999. Available from: <http://onlinelibrary.wiley.com/doi/10.1046/ j.1365-2036.1999.00579.x/epdf $>$. Accessed: Jun. 10, 2015. doi: 10.1046/j.1365-2036.1999.00579.x.

ROY, M.A. et al. Prevalence of ulcers of the squamous gastric mucosa in standardbred horses. Journal of Veterinary Internal Medicine, v.19, p.744-750, 2005. Available from: $<$ http://onlinelibrary.wiley.com/doi/10.1111/j.1939-1676.2005. tb02755.x/epdf $>$. Accessed: Jun. 11, 2015. doi: 10.1111/j.19391676.2005.tb02755.x

SCHAEFER, R. et al. Incidência de lesões gástricas em cavalos PSI de corrida em treinamento comparadas a cavalos de haras. Revista Acadêmica Ciências Agrárias e Ambientais, v.4, n.4, p. 6570, 2006. Available from: <file://C:/Users/Gesiane/Downloads/ academica-1033\%20(2).pdf>. Accessed: Jun. 11, 2015.

SHAWDON, A. Gastro-oesophageal reflux and exercise. Sports Medicine, v.20, p.109-116, 1995. Available from: <http:// link.springer.com/article/10.2165/00007256-19952002000005\#page-1>. Accessed: Jun. 11, 2015. doi: 10.2165/00007256199520020-00005.

TAMZALI, Y. et al. Prevalence of gastric ulcer syndrome in highlevel endurance horses. Equine Veterinary Journal, v.43, n.2, p.141-144, 2011. Available from: <http://onlinelibrary.wiley.com/ doi/10.1111/j.2042-3306.2010.00129.x/epdf $>$. Accessed: Jun. 08, 2015. doi: 10.1111/j.2042-3306.2010.00129x. 


\section{ERRATUM}

Artigo "Occurrence of gastric ulcers in horses exercised on a treadmill" publicado no fascículo v46n5 de maio de 2016 da Ciência Rural, onde se lia:

"Vanessa Aparecida Feijó"

leia-se:

"Vanessa Aparecida Feijó de Souza" 